Bangladesh J. Bot. 42(2): 247-255, 2013 (December)

\title{
IDENTIFICATION OF GOOD COMBINERS IN EARLY MATURING × HIGH YIELDING CULTIVARS OF INDICA RICE (ORYZA SATIVA L.)*
}

\author{
Mukesh Kumar Singh, Ravi P Singh and Prakash Singh ${ }^{1}$ \\ Department of Genetics and Plant Breeding, Institute of Agricultural Sciences, \\ Banaras Hindu University, Varanasi-221005, Uttar Pradesh, India
}

Key words: Indica rice, Line $\times$ tester design, GCA, SCA, Grain yield

\begin{abstract}
Line $\times$ tester analysis involving seven early maturing lines and four high yielding testers, made to produce $28 \mathrm{~F}_{1} \mathrm{~s}$ hybrids. The $\mathrm{F}_{1}$ data revealed that both additive and non-additive gene were important in controlling yield contribution in Indica rice. Variances were significant for GCA and SCA effects for all the characters indicating the significance of both additive and non-additive genes. There was high proportion of non-additive genes for the expression of different traits. Cultivars Anjali, MTU-7029 and BPT-5204 were identified as best general combiners for yield and yield traits among the parents. The most promising specific combiners for grain yield and its contributing traits were Govind $\times$ HUR 105, NDR $97 \times$ HUR 4-3, Anjali $\times$ HUR 4-3, NDR $97 \times$ MTU 7029, Vandana $\times$ BPT 5204, Shanthi $\times$ HUR 105, Anjali $\times$ MTU 7029 and Shanthi $\times$ BPT 5204 .
\end{abstract}

\section{Introduction}

Rice (Oryza sativa L., 2n = 24), a member of Poaceae (Gramineae) is world's most important staple food crop that feed over half of the global population. It is cultivated in tropical and subtropical regions. Rice is grown in more than 114 countries, over an area of $161.4 \mathrm{~m}$ ha in a wide range of ecosystems under varying temperature and water regimes with the production of $466.7 \mathrm{mt}$ (on milled basis) (FAO 2011). The total area under rice in India is about $45 \mathrm{~m}$ ha (22\% of cropped area) with an annual production of $103.4 \mathrm{mt}$ and contributes $25 \%$ to total agricultural GDP. The world population will grow up to 8.5 billion till 2030 for that about $40 \%$ more rice will be required to feed growing population (Khush 2006). Therefore, increasing its productivity is of high importance in breeding programmes. Plant breeding strategies should be made for selection of plants to achieve expected level of heterosis as well as the specific combining ability. Reduced plant height, effective tillers per hill, increased kernel number per panicle, increased 1000-grain weight and higher yield are the most important rice traits to be improved in breeding programmes (Paterson et al. 2005).

For, high yielding varieties of crop plant for qualitative and quantitative traits, plant breeders often face problems in selecting parents and crosses. Combining ability analysis is one of the most valuable tools to ascertain the combining ability effects and helps in selecting the desirable parents for making crosses and crosses for the exploitation of heterosis (Khatun et al. 2010). Line $\times$ tester analysis provides information related to general combining ability (GCA) and specific combining ability (SCA) effects of parents. This information is helpful in estimating various types of gene action (Chaudhury and Sasmal 1992, Ganapathy et al. 2007 and Akter et al. 2010). Therefore in the present investigation, an attempt was made to study combining ability (GCA and SCA) in rice cultivars for different traits to identifying good combiners, desirable cultivars to developing high yielding rice varieties.

*Part of Ph. D. thesis of the first author (MKS). ${ }^{1}$ Author for correspondence: <prakash201288@gmail.com> 


\section{Materials and Methods}

The experiment was conducted at Agricultural Farm, Institute of Agricultural Sciences, Banaras Hindu University, Varanasi, UP, India during Kharif 2008 - 2010. The material for the present investigation comprised 11 genetically diverse cultivars (Table 1), in which seven lines were used as male parents viz. Anjali $\left(\mathrm{P}_{1}\right)$, HUR 3022 (P2), Vandana (P3), Govind (P4), Annada (P5), NDR 97 (P6) and Shanthi (P7) and 4 lines (broad based varieties) were used as testers (female parents) viz., HUR 4-3 (P8), HUR 105 (P9), MTU 7029 (P10) and BPT 5204 (P11) of rice chosen on the basis of early maturity and high yielding potential, respectively. All the parents were crossed in all possible combinations in line $\times$ tester mating to produce $28 \mathrm{~F}_{1}$ s. The experiment comprising $28 \mathrm{~F}_{1} \mathrm{~s}$ along with their parents were evaluated in randomized block design (RBD) with three replications during Kharif seasons of 2008 - 2010. Twenty days old seedlings of each parents and $\mathrm{F}_{1}$,s (one seedling per hill) were transplanted in field. The spacing between row to row $20 \mathrm{~cm}$ and plant to plant $15 \mathrm{~cm}$ was maintained in $3 \mathrm{~m}$ row length in each plot. All recommended cultural practices and plant protection measures were followed.

Data were recorded for nine quantitative characters viz., panicle initiation, days to $50 \%$ flowering, days to maturity, plant height $(\mathrm{cm})$, effective tiller/plant, 1000-grain weight (g), spikelet fertility (\%) and grain yield/plant (g) on five randomly selected plant from all $\mathrm{F}_{1} \mathrm{~s}$ and parents in each replication. The randomly selected plants were tagged before maturity. Days to 50 per cent flowering and days to maturity were recorded on plot basis. The average of the five plants was taken as the mean value for each treatment and the mean values were used for statistical analysis. The pooled data were analyzed according to ANOVA (Steel and Torrie 1980). Combining ability (GCA and SCA) analysis was done using line $\times$ tester method (Kempthorne 1957) and the analysis was done using statistical software WINDOSTAT Ver. 8.3.

\section{Results and Discussion}

In the study, mean squares of parents and crosses showed significant difference $(\mathrm{p}<0.01)$ between cultivars for all the traits under study (Table 2). The difference between parents indicated that the experimental materials possessed considerable variability and they are suitable for genetic studies. The ANOVA for combining ability indicated that variances due to lines, testers and interaction effects (line $\times$ tester) were highly significant for all the characters. These trends indicated the presence of both additive and non-additive gene action. These results conform the findings of Sarker et al. (2002).

Further analysis of GCA/SCA variance showed that the nature of gene action as non-additive for all the traits. The SCA variances was higher for all the characters indicating the role of nonadditive gene, which results from dominance, epistasis and various other interaction effects with non fixable genetic variation. The presence of greater non-additive gene offers scope for exploiting hybrid vigour through heterosis breeding and hence these parents can be further exploited for production of good commercial variety. Khatun et al. (2010) and Amudha and Thiyagarajan (2011) also reported that non-additive gene action was greater than additive gene action for yield and most of the yield contributing traits.

The proportional contribution of lines, testers and their interaction for eight different traits are shown in Table 3. It is evident that lines played important role towards plant height (72.43\%), panicle initiation (60.99\%), days to 50\% flowering (60.13\%), days to maturity (59.02\%) and grain yield per plant (37.98\%) indicating predominant maternal influence on these traits. Testers were more important for 1000-grain weight (56.33\%), effective tiller per plant (30.07) and grain yield per plant (13.57\%). It revealed that preponderance influence for the traits. The contribution of paternal and maternal interaction (line $\times$ tester) were high for spikelet fertility (62.78), grain yield 


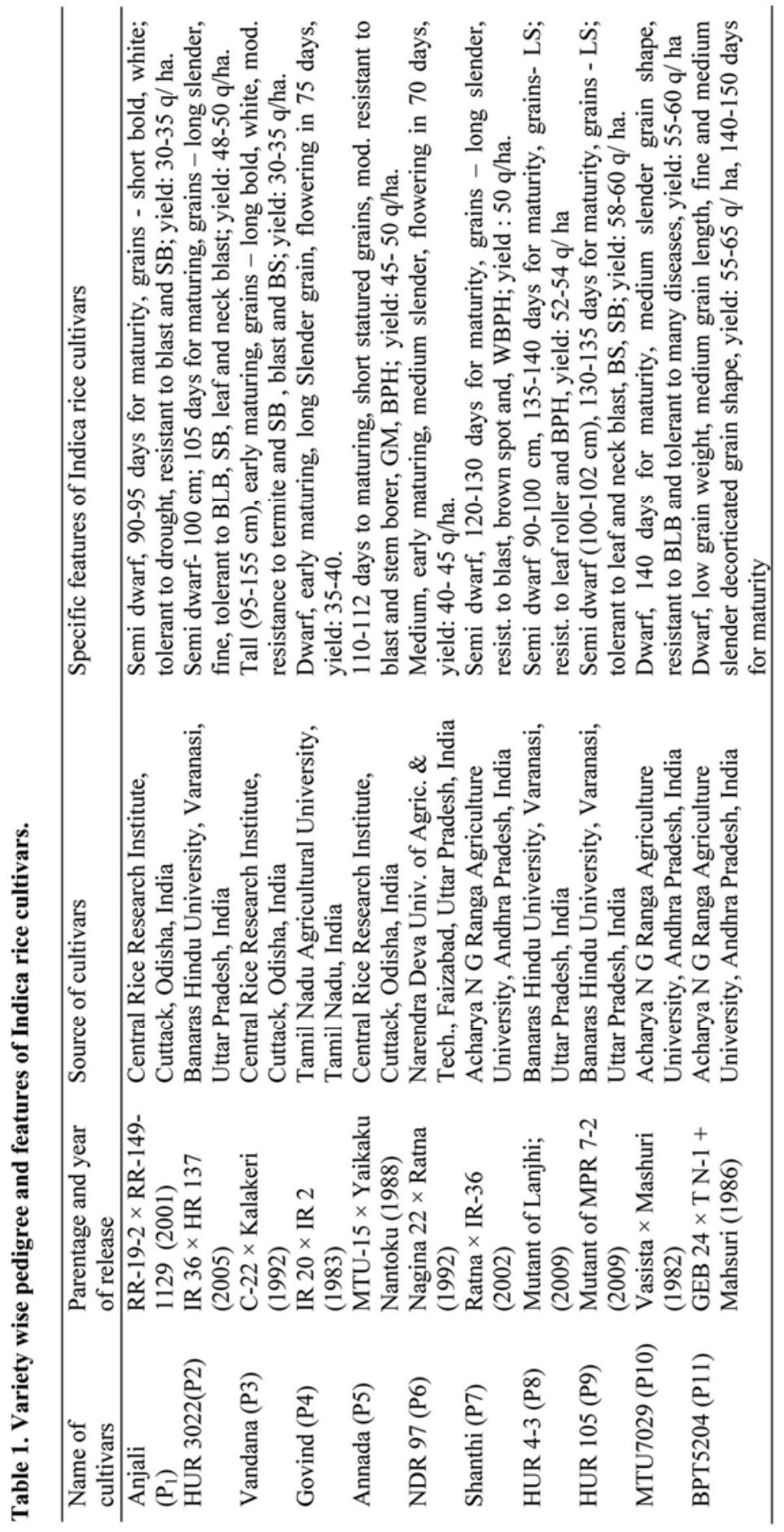



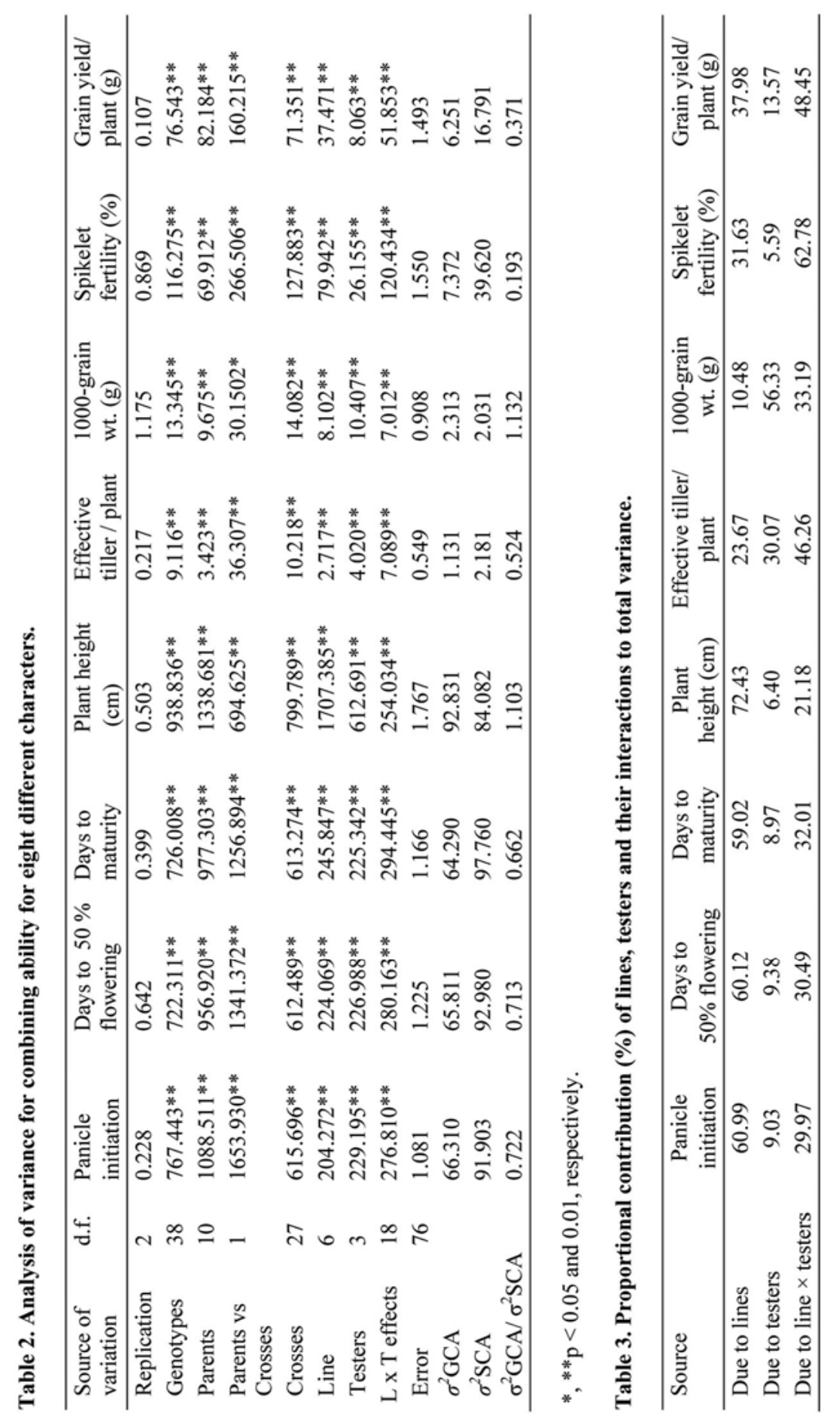
per plant (48.45\%) and effective tiller per plant (46.26\%) and were low for rest of all the characters. These results are similar to those reported by Sarker et al. (2002) and Rashid et al. (2007).

The estimates of general combining ability for parents (Table 4) revealed that none of the parents was a consistently good general combiner except Anjali (male parent) for all the traits studied. However, the female parents MTU 7029 and BPT 5204 were found to be good general combiner for grain yield per plant. High GCA effect of BPT 5204 for grain yield per plant was associated with in high GCA effect for effective tiller per plant, days to maturity, days to $50 \%$ flowering and panicle initiation, and significant negative GCA effect for 1000-grain weight and plant height. Better combining ability of MTU 7029 for grain yield per plant was due to its high GCA effect for spikelet fertility, days to maturity, days to 50\% flowering and panicle initiation, and negative significant GCA for effective tiller per plant. Likewise, male parent HUR 105 appeared to be good general combiner for days to maturity, plant hight and effective tiller per plant and 1000-grain weight while, male parent HUR 4-3 was good general combiner for spikelet fertility and negative for rest of the traits.

Among the male parents, Anjali was the better general combiner for all the traits under study and other male parents Annada and Vandana were the best general combiner for grain yield. High GCA effect of Annada for grain yield per plant may be associated with its high GCA effects for effective tiller per plant, days to maturity, days to $50 \%$ flowering and panicle initiation and plant height. In Vandana, high GCA effects for grain yield per plant, spikelet fertility and plant height were due to its negative GCA effects for days to maturity, days to $50 \%$ flowering and panicle initiation; Shanthi for effective tiller per plant, plant height, days to maturity, days to $50 \%$ flowering and panicle initiation and HUR 3022 for panicle initiation, days to 50\% flowering and days to maturity.

Negative GCA effects for plant height and positive GCA effect for other traits are desirable. Dwarf plants are required to protect the crop from lodging. Earliness is a desirable trait for aerobic and non aerobic condition of rice cultivation. Parents showing good combining ability were HUR 4-3, Vandana, Govind, NDR 97 (Table 4); these genotypes can be utilized for developing short duration variety.

On the basis of mean performance and GCA effects with respect to yield contributing traits, the lines Anjali, Vandana, Annada, Shanthi was a good general combiners for all yield contributing traits and tester MTU 7029 and BPT 5204 are good for grain yield per plant, panicle initiation, days to $50 \%$ flowering, days to maturity, effective tiller per plant and spikelet fertility. Therefore, these genotypes with desirable genes for yield and yield contributing traits can be used as potential donors for improvement of yield potential or yield with early maturity.

In contrast to general combining ability effects, the specific combining ability effects represents dominance and epistatic component of variation, that is not fixable in nature. But if crosses showing high SCA effect involved either both or one good general combing parents, they can be successfully exploited for varietal improvement and expected to throw stable performing transgressive segregants carrying fixable gene effects (Veged et al. 2011). The estimates of specific combining ability effects of 28 cross combinations for different yield contributing characters are presented in Table 5. It is observed that out of 28 crosses 14 crosses exhibited positive and significant SCA effects for grain yield per plant.

The promising specific combinations for grain yield and other traits were found in Govind $\times$ HUR 105, NDR $97 \times$ HUR 4-3, Anjali $\times$ HUR 4-3, NDR $97 \times$ MTU 7029, Vandana $\times$ BPT 5204, Shanthi $\times$ HUR 105, Anjali $\times$ MTU 7029 and Shanthi $\times$ BPT 5204. It is observed that majority of 


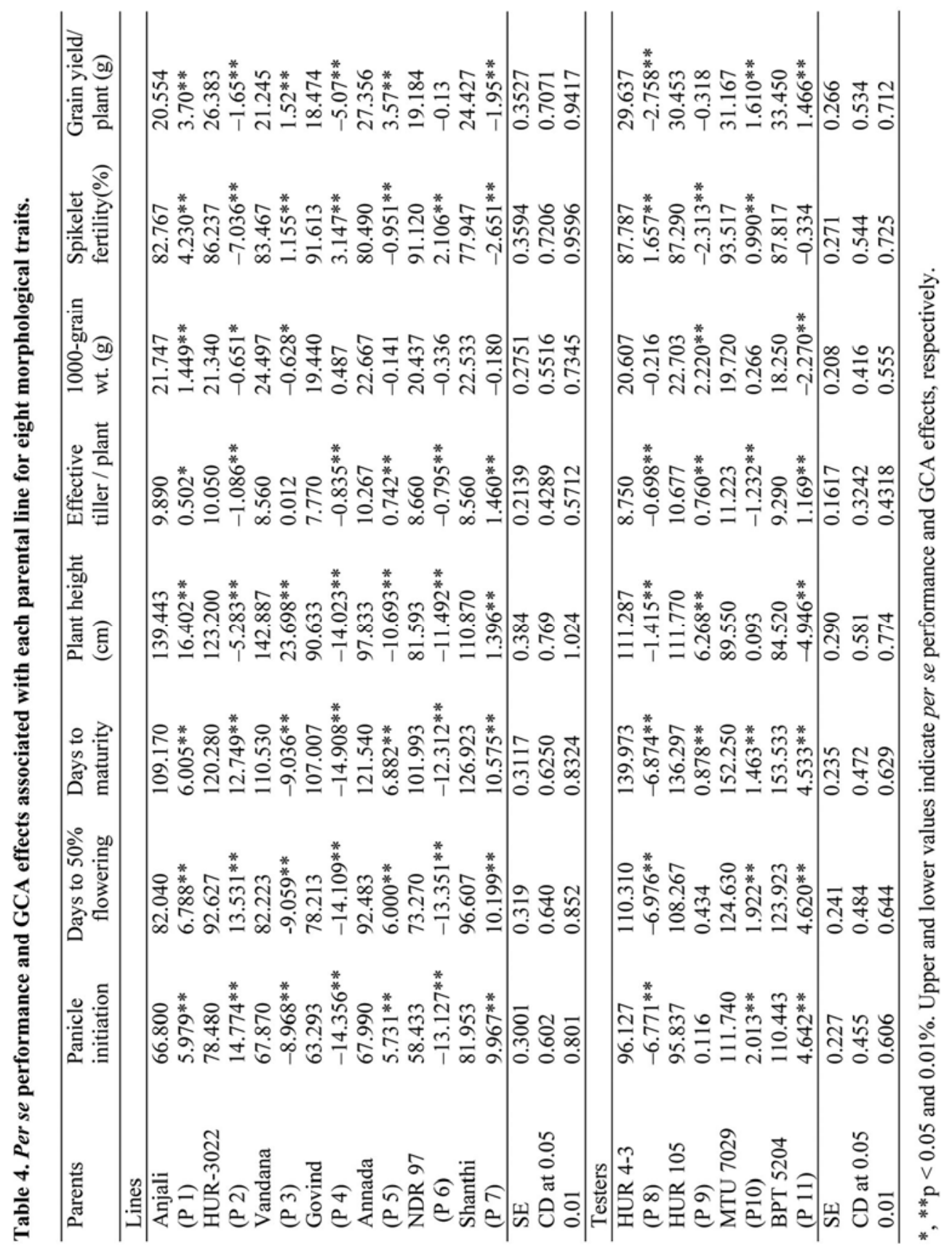




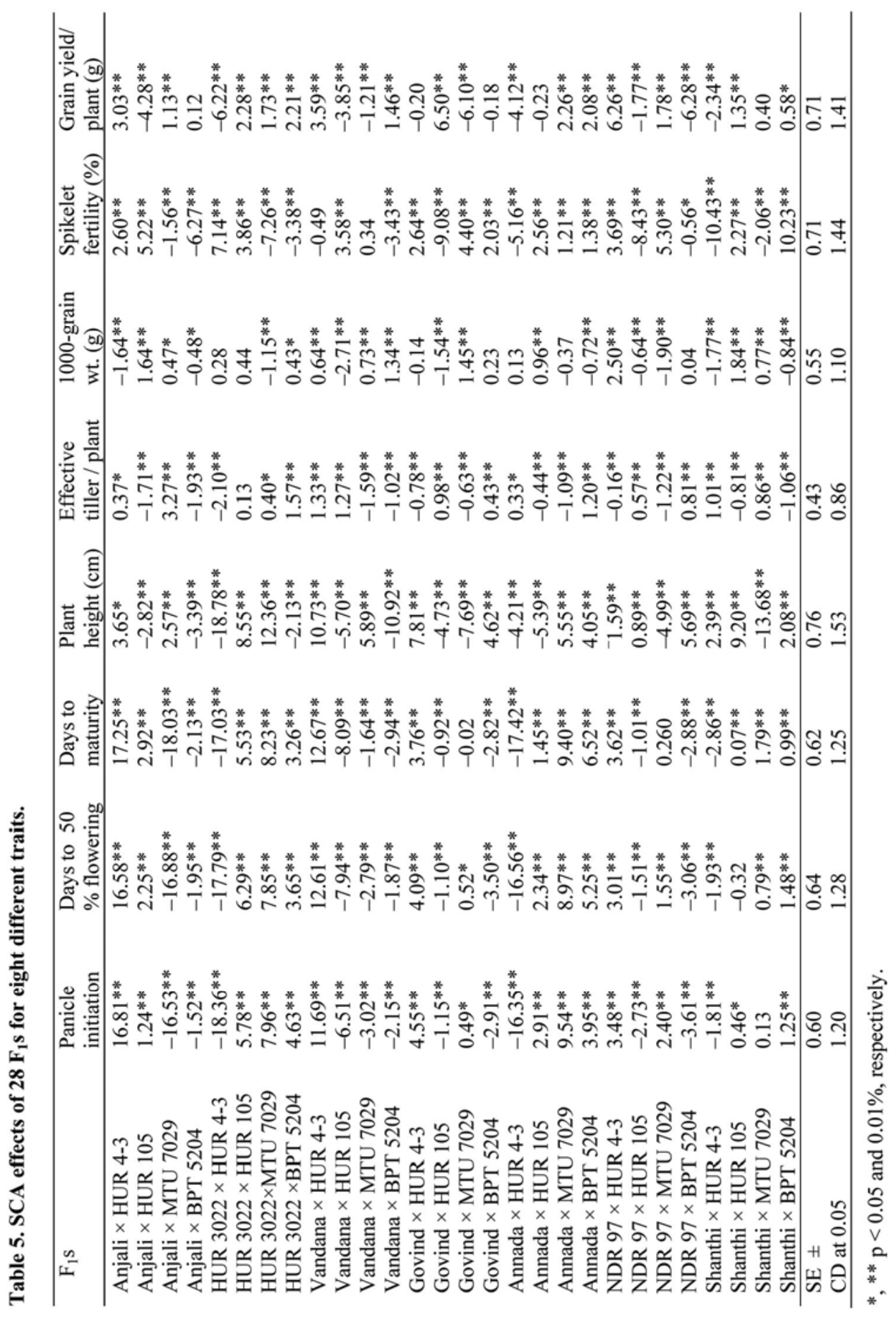


the crosses with high SCA effects for grain yield were involved with high $\times$ low combiners indicating additive $\times$ dominance type of gene interactions for expression of traits. Similarly crosses involving high $\times$ high general combiners showed high GCA effects which could be due to predominance of additive $\times$ additive gene action. Some crosses having low $\times$ low general combiners showed high SCA effect suggesting the epistatic gene action may be operating due to genetic diversity in the form of heterozygous loci. Thus in majority of the crosses, high SCA effects for grain yield were attributed to additive and dominance gene actions and a few cross attributed to epistatic interactions. These results were conformity of the finding of Pradhan and Singh (2008) and Amudha and Thiyagarajan (2011).

Negative estimates for SCA may be desirable for few traits like earliness and dwarf plant type, cross combination showing desirable SCA for earliness are Anjali $\times$ MTU 7029, HUR $3022 \times$ HUR 4-3 and Annada $\times$ HUR 4-3. The desirable cross combinations for dwarf plant type are HUR $3022 \times$ HUR 4-3 and Vandana $\times$ BPT 5204. These crosses are showing best negative and significant specific combining ability for plant height and earliness. The results are in conformity with the findings of Sarker et al. (2002) and Akter et al. (2010). Effective tiller per plant, spikelet fertility and 1000-grain weight are positively correlated with grain yield per plant; these traits may be used as selection criteria for screening of high yielding cultivars per variety. The Crosses showing high SCA effects for yield contributing traits were Anjali $\times$ HUR 105, Anjali $\times$ HUR 4-3, NDR $97 \times$ HUR 4-3 and Shanthi $\times$ HUR 105. NDR $97 \times$ HUR 4-3 cross possesses favourable alleles for yield contributing traits to exhibit significant SCA effect for morphological characters like panicle initiation, 1000-grain weight and spikelet fertility (Table 5).

It is concluded from the present study that the importance of good $\times$ good general combiners exhibiting high SCA effect can be utilized for improvement through single plant selection in segregating generations. But in crosses having high SCA effects due to good $\times$ poor general combiners may be improved through population improvement. The cross showing high SCA effects involving poor $\times$ poor general combiners may be utilized for heterosis breeding programme.

\section{References}

Akter A, Hasan MJ, Begum H, Kulsum MU and Hossain MK 2010. Combining ability analysis in rice (Oryza sativa L.). Bangladesh J. Pl. Breed. Genet. 23: 7-13.

Amudha K and Thiyagarajan K 2011. Combining ability analysis for morphological, physiological and root traits in aerobic rice. Oryza 48: 200-205.

Chaudhury SK and Sasmal BC 1992. Heterosis and combining ability for fibre strength in tossa jute (Corchorus olitoriuis L.). Bangladesh J. Bot. 21: 213-218.

FAO 2011. FAO (Food and Agriculture Organization of the United Nations) Database. http://www.faostat. fao.org/site/339/default.aspx.

Ganapathy S, Ganesh SK and Babu RC 2007. Evaluation of genetic potential of parents and their hybrids for drought tolerance in rice (Oryza sativa L.). International. J. Genet. Pl. Breed. 1: 82-88.

Kempthorne O 1957. An introduction of genetic statistics. John Willey and Sons Inc., New York. pp. 468473.

Khatun R, Sarkar RH and Sobhan MA 2010. Combining ability for yield and yield contributing characters of white jute (Corchorus capsularis L.). Bangladesh J. Bot. 39: 79-85.

Khush GS 2006. Rice Breeding: Accomplishment and challenges for future food security. Ritsumeikan International affairs 4: 25-36.

Paterson AH, Freeling M and Sasaki T 2005. Grains of knowledge: Genomics of model cereals. Genome Res. 15: $1643-1650$. 
Pradhan SK and Singh S 2008. Combining ability and gene action analysis for morphological and quality traits in basmati rice. Oryza 45: 193-197.

Rashid M, Cheema AA and Ashraf M 2007. Line $\times$ tester analysis in basmati rice. Pakistan J. Bot. 39: 20352042.

Sarker U, Biswas PS, Prasad B and Khaleque-Mian MA 2002. Heterosis and genetic analysis in rice hybrids. Pak. J. Biol. Sci. 5: 1-5.

Steel RD and Torrie JH 1980. Principal and Procedures of Statistics. McGraw Hill Book Co., New York.

Veged PM, Vaddoria MA, Mehta DR and Naghera YV 2011. Combining ability analysis in bottle gourd. Crop Improv. 38: 13-17.

(Manuscript received on 8 September, 2012; revised on 30 October, 2013) 